\title{
Genetic Components Estimation of F1 Population of Cocoa (Theobroma cacao L.) in Drought Stress Condition
}

\author{
Adinda Wuriandani ${ }^{1)}$, Sobir ${ }^{1 *}$, Desta Wirnas ${ }^{1)}$, and Agung Wahyu Susilo ${ }^{2)}$ \\ ${ }^{1}$ Faculty of Agriculture, IPB University, Dramaga, Bogor \\ ${ }^{2)}$ Indonesian Coffee and Cocoa Research Institute, Jl. PB. Sudirman 90, Jember \\ ${ }^{*}$ Corresponding author: rsobir@yahoo.com \\ Received: 15 July 2019 / Accepted: 6 August 2019
}

\begin{abstract}
Drought stress is a major constraint in cocoa production. The use of drought tolerant clone is the most efficient tool to overcome drought problem in cocoa production. North Carolina II (NCII) mating-design was used to identify parental and progeny performance in drought stress. The crossing consisted of three female parent clones namely KW 516, Sulawesi 3, and TSH 858, while male parent clones were ICCRI 09 and Scavina 6 then produced 6 combinations crosses. Genotypes used were 11 genotypes consisted of 5 parent clones and 6 cross genotypes. Drought treatment was applied to cocoa seedlings at 6 weeks after sowing with $25 \%$ and $100 \%$ available water content. The plants were maintained without water for five days to modulate the drought intensity. Variables observed were stem diameter, root length, root volume, shoot fresh weight, root fresh weight, shoot dry weight, root dry weight, and root/shoot ratio characters at 16 weeks after sowing. Based on the estimated general combining ability (GCA) value, TSH 858 was the best female parent, while Scavina 6 was the best male parent. Based on the estimated specific combining ability (SCA) value Sulawesi 3 x ICCRI 09 and TSH 858 x Scavina 6 were the best crosses. Based on the estimation of its genetic components, characters of drought tolerance stress were affected by additive genes. The dominant gene only affected the root fresh weight and root/shoot ratio. Based on SSI values, TSH 858 and Sulawesi 3 clones were drought-resistant clones, ICCRI 09 was moderate clone, and KW 516 and Scavina 6 were susceptible. Some of the findings were in contrast with earlier study.
\end{abstract}

Keyword: Drought stress, GCA, SCA, North Carolina II (NCII), genetic component, Theobroma cacao

\section{INTRODUCTION}

Cocoa is one of the leading agriculture and industrial crops in Indonesia. Indonesia is the third largest cocoa producer in the world after Ivory Coast and Ghana (ICCO, 2017). Cocoa production in Indonesia in the last 5 years has decreased by 32 thousand tons (Ditjenbun, 2017). According to BPS (2018), national cocoa production in 2016 reached 658399 tons and in 2017 national cocoa production decreased by 1349 tons. One factor that causes low cocoa production is abiotic factors such as drought stress (Alban et al., 2016).

Drought can affect decreasing of plant growth and development both in the seedling phase and in mature plants. The impact of drought stress can be overcome by the development of superior drought resistant hybrid clones. Development of superior hybrid clones require 
a good plant breeding strategy. Monsterin \& Verteuil (1956) have found heterosis in cocoa plants so that almost all plant breeding programs in cocoa plants refer to the development of inter-clonal hybrids (full-sib families) (Lopes et al., 2011). The development program also adopted a "single-generation breeding" strategy where new hybrids will be developed from existing germplasm, not from selected progenies in the advanced generation (Lopes et al., 2011).

According to Lopes et al. (2011), one of the crossing designs that can be used to develop a cocoa plant population is North Carolina II (NCII). Each member of the male parents used is crossed with each member of the female parents in NCII mating-design (Nduwumuremyi et al., 2013). According to Hallauer (2007), NCII mating-design is suitable for use in a large number of parent but only produces fewer crosses. The design of NCII is similar to the line $\mathrm{x}$ tester matingdesign. This is because the two matingdesigns both calculate the influence of the variance of female parents and the variance of male parents, as well as the influence of the interaction of female $\mathrm{x}$ male parents (Fasahat et al., 2016).

Through analysis combining ability at the parents used in the mating-design, the parent combination will be obtained with the best combined ability value. Combining ability is the ability of parents to be used to combine with other parents through a crossing process (Fasahat et al., 2016). According to Sprague \& Tatum (1942), there are two types of combining ability: general combining ability (GCA) and specific combining ability (SCA). General combining ability (GCA) is the average performance value of the parent used in a cross. Specific combining ability (SCA) is the average performance value of a combination compared to the parent used (Acquaah, 2012). The GCA value is related to the additive gene, while the SCA value is related to non-additive gene (Fasahat et al., 2016).

Aims of this research were to obtain estimated values of genetic components through NCII mating-design. The best parent were expected to drought tolerance based on GCA and SCA values also the best genotypes with the best tolerance levels.

\section{MATERIALS AND METHODS}

This research was conducted from August 2018 until May 2019. The research was conducted at Kaliwining Experimental Station, Indonesian Coffee and Cocoa Research Institute. Planting activity after crossing and produced genotypes F1 was carried out at Greenhouse Kaliwining Experimental Station, Indonesian Coffee and Cocoa Research Institute.

This research started with crossing using North Caroline II (NCII) mating-design (Lopas et al., 2011). Female parent clones were TSH 858, KW 516, and Sulawesi 3 , while male parent clones were Scavina 6 and ICCRI 09. While, KW 516 classified in drought tolerant clone (Zakariyya et al., 2017), Sulawesi 3 and Scavina 6 were moderate clone (Towaha \& Wardiana, 2015), and TSH 858 was susceptible clone (Iryono, 2010; Kurniawan, 2017). Total combination of crosses produced through the design were 6 combinations of crosses (Table 1). Planting materials in this research consisted of 6 crosses (offspring) and 5 parent clones.

Table 1. Cross combination used in the research

\begin{tabular}{|c|c|c|c|}
\hline $\begin{array}{l}\text { Male } \\
\text { Female }\end{array}$ & TSH 858 (T3) & Sulawesi 3 (T4) & KW 516 (T5) \\
\hline ICCRI 09 (T1) & $\mathrm{T} 1 \times \mathrm{T} 3$ & $\mathrm{~T} 1 \times \mathrm{T} 4$ & T1 $\times$ T5 \\
\hline Scavina 6 (T2) & $\mathrm{T} 2 \times \mathrm{T} 3$ & $\mathrm{~T} 2 \times \mathrm{T} 4$ & $\mathrm{~T} 2 \times \mathrm{T} 5$ \\
\hline
\end{tabular}


Soil analysis used the $\mathrm{pF}$ curve to determine the permanent wilt point and field capacity of the soil used in first research preparation. Polybag size was $15 \times 25 \mathrm{~cm}$. Drought stress treatment was given to plants at 1.5 months old (6 week after sowing). Drought treatments were of $100 \%$ and $25 \%$ available water content (AWC). The plants were maintained without water for 5 days to modulate the drought intensity.

Observations were made on plant morphological characters such as: stem diameter, root length, root volume, shoot fresh and dry weight, root fresh and dry weight, and root/shoot ratio. This observation was finished at 4 months old (16 week after sowing).

Data which had been collected $(25 \%$ AWC treatment) would be analyzed using NCII mating-design. R 3.4 version was used as software analysis. Linear additive models for analysis of variance using NCII is:

$$
\begin{array}{ll}
Y_{i j k} & =\mu+m_{i}+f_{j}+(m \times f)_{i j}+\varepsilon_{i j k} \\
\mathrm{Y}_{\mathrm{ijk}} & =\text { observation value } \mathrm{k} \text { on cross combination } \mathrm{i} \times \mathrm{j} \\
\mu & =\text { overall data mean } \mathrm{Y} \\
\mathrm{m}_{\mathrm{i}} & =\text { male parent influence to } \mathrm{i} \\
\mathrm{f}_{\mathrm{j}} & =\text { female parent influence to } \mathrm{j}, \\
(\mathrm{m} \times \mathrm{f})_{\mathrm{ij}} & =\text { interaction between male parent to } \mathrm{i} \text { and female } \\
& \text { parent to } \mathrm{j} \\
\varepsilon_{\mathrm{ijk}} & =\text { error }
\end{array}
$$

NCII mating design results consisted of GCA on the parents used, value of SCA on the cross combination produced, variance of $\operatorname{GCA}\left(\sigma_{\mathrm{GCA}}^{2}\right)$, variance of $\mathrm{SCA}\left({ }_{\mathrm{SCA}}\right)$, variance additives $\left({ }_{A}\right)$, and variance dominant $\left({ }_{D}\right)$. This value was then used to estimate the value of broad sense heritability $\left(\mathrm{h}_{\mathrm{bs}}^{2}\right)$ and narrow sense heritability $\left(\mathrm{h}^{2}{ }_{\mathrm{ns}}\right)$.

Clones grouping used their tolerance ability to drought based on the value of the Stress Susceptibility Index (SSI) (Ali \& El-Sadek, 2016; Khan \& Dhurve, 2016) with the formula:

$$
S S I=\frac{\left(1-\frac{Y}{Y_{p}}\right)}{\left(1-\frac{X}{X_{p}}\right)}
$$

$\mathrm{Y}=$ observation value of variable on the genotypes with drought stress

$\mathrm{Yp}=$ observation value of variable on the genotypes with optimum environment

$\mathrm{X}=$ the mean value of variable on the genotypes with drought stress

$\mathrm{Xp}=$ the mean value of variable on the genotypes with optimum environment

Cocoa plants with SSI value of $<0.5$ are classified as drought tolerant plants, plants with $0.5<\mathrm{SSI}<1$ are classified as moderate to drought stress (Setyawan et al., 2018), and plants with SSI $>1$ are classified as susceptible to drought stress (Helmi, 2017).

\section{RESULTS AND DISCUSSION}

Research about drought stress in plants has been carried out. Some studies suggest that the characters associated with the root system have important role in response to drought stress in plant (Alban et al., 2016; Medina \& Laliberte, 2017; Setyawan et al., 2018). These characters include stem diameter, root length, root volume, shoot and root fresh weight, shoot and root dry weight, and root/ shoot ratio.

Based on the results analysis of variance, genotypes used in this study were significantly different. Analysis of variance based on NCII found that all observed characters were significantly different in crossing genotypes, except for root dry weight. Female parents and male parents showed significant differences performance in root dry weight. This means that on the character of root dry weight there is an effect produced both from female parents and male parents. The female parents used only showed significant differences in character shoot fresh weight, and shoot dry weight 
(Table 2). This indicates that the influence of female parents is very large on the characters of shoot fresh and dry weights.

The results of general combined ability analysis (GCA) show that TSH 858 was the best female parent because it had the highest GCA values in almost all characters, except root length and root/shoot ratio. Scavina 6 was the best male parent that had highest GCA value in almost all characters, except stem diameter, root fresh weight, and root dry weight (Table 3). TSH 858 clone is commonly used for parent material because it has high productivity (Kementan, 2013). Scavina 6 clone is also widely used for the formation of superior hybrids in cocoa plants. According to Zakariyya (2017), Scavina 6 clone has high seedling root length. The highest estimated value of specific combining ability (SCA) was
Sulawesi 3 x ICCRI 09 in all observed characters except the root/shoot ratio. TSH 858 x Scavina 6 crosses also showed high SCA values in all observed characters except shoot dry weight character (Table 4). According to Hossein \& Aziz (1998), the high value of a GCA in a character does not always produce high value of SCA.

Positive values indicate a contribution to a higher phenotype value. The high value of combining ability was needed on the character associated with tolerance to drought, especially in the plant root system. This shows that a good root system will determine genotypes that are tolerant to drought. The growth of a good stem diameter is related to the physiological mechanism for translocation and assimilate storage, especially in stressed conditions (Santos et al., 2016). Good root development will also

Table 2. Variance analysis of the stem diameter and root system characters with NCII mating-design in $25 \%$ AWC treatment

\begin{tabular}{|c|c|c|c|c|c|c|c|c|c|}
\hline \multirow{2}{*}{$\begin{array}{l}\text { Source of } \\
\text { variation }\end{array}$} & \multirow{2}{*}{ df } & \multicolumn{8}{|c|}{ Mean square (MS) } \\
\hline & & SD & RL & RV & SFW & RFW & SDW & RDW & $\mathrm{R}$ \\
\hline Replication & 4 & $0.0154 *$ & $57.87 *$ & $22.36 *$ & $17.94 *$ & $12.34 *$ & $1.55 *$ & $0.177 *$ & $0.013 *$ \\
\hline $\mathrm{F} 1$ & 5 & $0.0030 *$ & $4.20 *$ & $1.09 *$ & $4.46 *$ & $0.91 *$ & $0.53 *$ & 0.023 ns & $0.014 *$ \\
\hline Female parent & 2 & $0.0025^{\mathrm{ns}}$ & 9.04 ns & $1.74^{\text {ns }}$ & $10.14 *$ & 1.07 ns & $1.25 *$ & $0.04 *$ & $0.028^{\text {ns }}$ \\
\hline Male parent & 1 & $0.0001^{\mathrm{ns}}$ & $1.38^{\mathrm{ns}}$ & 1.27 ns & 0.89 ns & 1.38 ns & 0.003 ns & $0.033 *$ & $0.0006^{\mathrm{ns}}$ \\
\hline Female * Male & 2 & $0.0049 *$ & $0.76^{\mathrm{ns}}$ & $0.34^{\text {ns }}$ & 0.57 ns & $0.52 *$ & $0.063 *$ & 0.00028 ns & $0.0058^{\mathrm{ns}}$ \\
\hline Error & 40 & 0.0002 & 0.38 & 0.17 & 0.20 & 0.16 & 0.016 & 0.013 & 0.0028 \\
\hline
\end{tabular}

Table 3. Estimated values of general combining ability (GCA) in female dan male parents in $25 \%$ AWC treatment

\begin{tabular}{|c|c|c|c|c|c|c|c|c|}
\hline \multirow{2}{*}{ Female } & \multicolumn{8}{|c|}{ Character } \\
\hline & SD & RL & RV & SFW & RFW & SDW & RDW & $\mathrm{R}$ \\
\hline KW 516 & -0.006 & -0.54 & -0.4 & -0.522 & -0.368 & -0.091 & 0.005 & -0.003 \\
\hline Sulawesi 3 & -0.12 & 1.098 & -0.034 & -0.638 & 0.115 & -0.3 & -0.067 & 0.54 \\
\hline TSH 858 & 0.018 & -0.557 & 0.433 & 1.161 & 0.254 & 0.39 & 0.061 & -0.052 \\
\hline SE GCA Female & 0.005 & 0.19 & 0.13 & 0.14 & 0.13 & 0.04 & 0.04 & 0.017 \\
\hline \multirow{2}{*}{ Male } & \multicolumn{8}{|c|}{ Character } \\
\hline & SD & RL & RV & SFW & RFW & SDW & RDW & $\mathrm{R}$ \\
\hline ICCRI 09 & 0.001 & -0.215 & -0.206 & -0.172 & 0.215 & -0.01 & 0.033 & -0.004 \\
\hline Scavina 6 & -0.001 & 0.215 & 0.206 & 0.172 & -0.215 & 0.01 & -0.033 & 0.004 \\
\hline SE GCA Male & 0.004 & 0.16 & 0.11 & 0.12 & 0.105 & 0.03 & 0.03 & 0.014 \\
\hline
\end{tabular}


Table 4. Estimated values of specific combining ability (SCA) in cross combination in this research in $25 \%$ AWC treatment

\begin{tabular}{lrrrrrrrr}
\hline \multirow{2}{*}{ Genotypes } & \multicolumn{7}{c}{ Character } \\
\cline { 2 - 8 } & \multicolumn{1}{c}{ SD } & RL & \multicolumn{1}{c}{ RV } & SFW & RFW & SDW & RDW & R \\
\hline KW 516 x ICCRI 09 & 0.015 & 0.05 & -0.011 & -0.177 & 0.093 & -0.046 & 0.002 & -0.027 \\
KW 516 x Sca 6 & -0.015 & -0.05 & 0.011 & 0.177 & -0.093 & 0.046 & -0.002 & -0.027 \\
Sul 3 x ICCRI 09 & 0.011 & 0.248 & 0.189 & 0.271 & 0.123 & 0.046 & 0.004 & -0.01 \\
Sul 3 x Sca 6 & -0.011 & -0.248 & -0.189 & -0.271 & -0.123 & -0.046 & -0.004 & 0.01 \\
TSH 858 x ICCRI 09 & -0.025 & -0.297 & -0.178 & -0.094 & -0.217 & 0.001 & -0.006 & -0.018 \\
TSH 858 x Sca 6 & 0.025 & 0.297 & 0.178 & 0.094 & 0.217 & -0.001 & 0.006 & 0.018 \\
SE SCA & 0.006 & 0.27 & 0.18 & 0.2 & 0.32 & 0.056 & 0.051 & 0.024 \\
\hline Note: SD = stem diameter, RL = root length, RV= root volume, SFW = shoot fresh weight, RFW = root fresh weight, &
\end{tabular}

support plant growth, biomass formation, and drought resistance (Santos et al., 2016). Roots will respond to drought conditions by extending their roots to more easily access deeper water. The high ratio of plant roots and shoot is needed. According to Beets et al. (2007) the higher root/shoot ratio will result in stronger plants (especially the seedling phase).

The effect of gene action on a plant character can be seen through range of $\mathrm{GCA}\left({ }_{\mathrm{GCA}}\right)$ and $\mathrm{SCA}\left({ }_{\mathrm{SCA}}\right)$. This is indicated by the ratio value of variance $\mathrm{GCA}\left({ }_{\mathrm{GCA}}\right)$ and variance SCA $\left({ }_{\mathrm{SCA}}\right)\left({ }_{\mathrm{GCA}} / \mathrm{SCA}\right)$. According to Istipliler et al. (2015), if the value of ${ }_{\mathrm{GCA}} /$ ${ }_{\text {SCA }}$ is smaller than the value of dominance ratio degree $\left({ }_{D} / A_{A}\right)^{1 / 2}$ in a character, it can be said that the character is controlled by the dominant gene. This is in line with the research conducted by Constantine (2017) on oil palm, where if the ratio of ${ }_{\mathrm{GCA}} / \mathrm{SCA}$ is smaller than the value of dominance ratio degree $\left({ }_{D} /{ }_{A}\right)^{1 / 2}$ then the character is influenced by non-additive factors.

The results genetic component values in this research can be seen in Table 5. Root length, root volume, shoot fresh weight, and shoot dry weight characters showed ratio of $\sigma_{\text {DGU }}^{2} J_{\text {DGK }}$ is higher than the value of dominance ratio degree $\left({ }_{D} / A^{1 / 2}\right.$ (Table 5). This result indicated that root length, root volume, shoot fresh weight, shoot dry weight characters were influenced by additive genes. The root fresh weight and root/shoot ratio characters showed the opposite value. Ratio value of ${ }_{\mathrm{DGU}}{ }_{\mathrm{DGK}}$ was smaller than the value of dominance ratio degree $\left({ }_{D} / A^{1 / 2}\right.$. Root fresh weight and root/shoot ratio characters were influenced by non-additive genes (dominant genes).

Root fresh weight and root/shoot ratio character showed a low value of narrow sense heritability $\left(\mathrm{h}^{2}{ }_{\mathrm{ns}}\right)$ (Table 5). Low value of narrow sense heritability $\left(\mathrm{h}^{2}{ }_{\mathrm{ns}}\right)$, in line with $\sigma_{\text {DGU }}^{2} /{ }_{\text {DGK }}$ value which is smaller than the value of $\left({ }_{D} / A^{1 / 2}\right.$ indicating that the character is affected by the effect of the dominant gene (Istipliler et al., 2015). Broad sense heritability $\left(\mathrm{h}_{\mathrm{bs}}^{2}\right)$ showed a high value in stem diameter, root length, shoot fresh weight, shoot dry weight. This result indicated that genetic effect was greater than environment effect. Heritability values can be classified in three classification. High if $\mathrm{H}$ value is $>$ $50 \%$, moderate $20 \%<\mathrm{H}<50 \%$, and low $\mathrm{H}<20 \%$ (Syukur et al., 2012).

This result showed that characters which related to drought stress tolerance were strongly influenced by the additive gene rather than the dominant gene. Drought stress tolerance in plant character is influenced by many genes and interactions between genes and their environmental effect (Tardieu \& Tuberosa, 2010; Luke et al., 2015). In corn, additive gene action is more prominent in drought stress conditions. Conversely, under 
normal conditions, the effects of additive and non-additive genes will affect controlling a character in plants (Derera et al., 2008).

The contribution proportion shows how much contribution of female parents, male parents, and their interactions for each character (Istipliler et al., 2015; Constantine, 2017). The results of the analysis found that all characters were strongly influenced by female parents except for stem diameter character. This result showed that female parents had high influences in almost all observed characters. The stem diameter character showed the highest proportion value derived from the interaction between female $x$ male parents $(65.59 \%)$. The contribution of female parents was higher in the character of root length $(86.15 \%)$, root volume (64.15\%), shoot fresh weight $(90.09 \%)$ root fresh weight $(46.87 \%)$, shoot dry weight (95.09\%), root dry weight $(71.25 \%)$, root/ shoot ratio $(82.32 \%)$ compared to the proportion of male parents (Table 6).

Mean values of 11 genotypes showed the best genotypes in each observed character.
KW516 genotype was the best genotype for stem diameter character. The highest value for root length was showed in ICCRI 09, but this value did not significantly different with Sulawesi 3, TSH 858, Sulawesi 3 x ICCRI 09, and Sulawesi 3 x Scavina 6. ICCRI 09 also showed the highest value in root volume character and root dry weight character. The highest mean values of shoot fresh and dry weight characters were showed in TSH 858 x Scavina 6 with $6.43 \mathrm{~g}$ and $2.30 \mathrm{~g}$, respectively. The highest values of root fresh weight and root/shoot ratio, were found in genotype TSH 858 and Sulawesi 3 (Table 7).

Selection of tolerant genotype to drought stress cannot only be seen through mean value. The mean value shown can only rank which genotypes are best for a particular character. Some studies on tolerance to stress indicate that determining a tolerant genotype requires a calculation such as stress susceptibility index (SSI) (Helmi, 2017; Setyawan et al., 2018).

The sensitivity index of drought stress is reflected through the value of SSI. SSI values

Table 5. Estimated genetic component value of the root characters in $25 \%$ AWC treatment

\begin{tabular}{|c|c|c|c|c|c|c|c|c|}
\hline \multirow{2}{*}{$\begin{array}{l}\text { Genetic } \\
\text { component }\end{array}$} & \multicolumn{8}{|c|}{ Character } \\
\hline & SD & RL & RV & SFW & RFW & SDW & RDW & $\mathrm{R}$ \\
\hline$\sigma_{\mathrm{GCA}}^{2}$ & 0 & 0.164 & 0.04 & 0.185 & 0.019 & 0.022 & 0.001 & 0.0004 \\
\hline$\sigma_{\mathrm{SCA}}^{2 \mathrm{GAA}}$ & 0.00094 & 0.076 & 0.034 & 0.074 & 0.072 & 0.0094 & 0 & 0.0006 \\
\hline$\sigma_{\mathrm{A}}^{2 \mathrm{CA}}$ & 0 & 0.33 & 0.071 & 0.37 & 0.037 & 0.044 & 0.0022 & 0.0008 \\
\hline$\sigma^{2}$ & 0.00093 & 0.08 & 0.034 & 0.073 & 0.07 & 0.009 & 0 & 0.0006 \\
\hline$\sigma^{2}{ }_{\mathrm{GCA}}{ }^{\mathrm{DSCA}}$ & 0 & 2.158 & 1.176 & 2.5 & 0.264 & 2.340 & 0 & 0.67 \\
\hline$\left(\sigma^{\text {GCA SCA }} / \sigma^{2}\right)^{1 / 2}$ & 0 & 0.492 & 0.692 & 0.44 & 1.375 & 0.452 & 0 & 1 \\
\hline $\mathrm{h}^{2}{ }_{\mathrm{ns}}^{\mathrm{D}}$ & 0 & 0.418 & 0.258 & 0.58 & 0.139 & 0.639 & 0.143 & 0.19 \\
\hline$h^{2_{b s}}$ & 0.823 & 0.519 & 0.382 & 0.69 & 0.401 & 0.769 & 0.143 & 0.33 \\
\hline
\end{tabular}

Table 6. The contribution rates of female parents, male parents, and female $\mathrm{x}$ male parents interaction for hybrid generation $(\%)$ in $25 \%$ AWC treatment

\begin{tabular}{|c|c|c|c|c|c|c|c|c|}
\hline \multirow{2}{*}{$\begin{array}{l}\text { Contribution } \\
\text { rates }\end{array}$} & \multicolumn{8}{|c|}{ Character } \\
\hline & SD & RL & RV & SFW & RFW, $\mathrm{g}$ & SDW, g & RDW, g & $\mathrm{R}$ \\
\hline Female & 34.05 & 86.15 & 64.15 & 90.09 & 46.87 & 95.09 & 71.25 & 82.32 \\
\hline Male & 0.36 & 6.59 & 23.42 & 2.18 & 30.4 & 0.12 & 28.27 & 0.82 \\
\hline Female x Male & 65.59 & 7.26 & 12.42 & 7.73 & 22.73 & 4.79 & 0.48 & 16.86 \\
\hline
\end{tabular}


below 0.5 indicate tolerant of drought stress genotype, the SSI value between 0.5 and 1 indicate moderate to drought stress genotype, whereas if the SSI value is greater than 1 indicate susceptible to drought stress (Helmi, 2017; Setyawan et al., 2018). Genotypes classified as tolerant to drought stress were Sulawesi 3, TSH 858, and KW 516 x ICCRI 09 (Figure 1). In previous studies showed that TSH 858 was the susceptible clone to drought (Iryono, 2010; Kurniawan, 2017).
Moderate genotypes were ICCRI 09, KW 516 x Scavina 6, Sulawesi 3 x ICCRI 09, and TSH 858 x ICCRI 09. Genotypes KW 516, Scavina 6, Sulawesi 3 x Scavina 6, and TSH 858 x Scavina 6 were susceptible to drought stress, this in contrast with many prior trials. Based on SSI values, drought tolerant parents were Sulawesi 3 and TSH 858, moderate parents were ICCRI 09, and susceptible parents were KW 516 and Scavina 6 (Figure 1).

Table 7. Mean values of observed characters on 11 genotypes in $25 \%$ AWC treatment

\begin{tabular}{|c|c|c|c|c|c|c|c|c|}
\hline \multirow{2}{*}{$\begin{array}{l}\text { Genotypes } \\
\text { Parents }\end{array}$} & \multicolumn{8}{|c|}{ Character } \\
\hline & SD & RL & RV & SFW & RFW & SDW & RDW & $\mathrm{R}$ \\
\hline KW 516 & $0.55 \mathrm{a}$ & $17.48 \mathrm{bc}$ & $3.73 \mathrm{ab}$ & $4.73 \mathrm{~cd}$ & $2.90 \mathrm{ab}$ & $2.25 \mathrm{a}$ & $0.77 b-d$ & $0.34 \mathrm{e}-\mathrm{g}$ \\
\hline ICCRI 09 & $0.53 b$ & $18.60 \mathrm{a}$ & $4.10 \mathrm{a}$ & $5.93 \mathrm{ab}$ & $2.77 \mathrm{ab}$ & $1.93 b$ & $0.94 \mathrm{a}$ & $0.48 \mathrm{ab}$ \\
\hline Scavina 6 & $0.45 \mathrm{f}$ & $16.90 \mathrm{c}-\mathrm{e}$ & $3.20 \mathrm{ab}$ & $4.07 \mathrm{e}$ & $2.60 \mathrm{a}-\mathrm{c}$ & $1.59 \mathrm{de}$ & $0.75 b-e$ & $0.46 \mathrm{a}-\mathrm{c}$ \\
\hline Sulawesi 3 & $0.48 \mathrm{de}$ & $18.49 \mathrm{a}$ & $3.50 \mathrm{ab}$ & $4.57 \mathrm{de}$ & $2.67 \mathrm{a}-\mathrm{c}$ & $1.62 \mathrm{de}$ & $0.82 \mathrm{a}-\mathrm{c}$ & $0.51 \mathrm{a}$ \\
\hline TSH 858 & $0.51 b c$ & $17.73 \mathrm{a}-\mathrm{c}$ & $3.13 b-d$ & $5.27 \mathrm{bc}$ & $3.03 \mathrm{a}$ & $2.23 \mathrm{a}$ & $0.64 \mathrm{e}$ & $0.28 \mathrm{~g}$ \\
\hline \multicolumn{9}{|l|}{$\begin{array}{l}\mathrm{F} 1 \\
\end{array}$} \\
\hline KW 516 x ICCRI 09 & $0.50 \mathrm{~cd}$ & $16.58 \mathrm{de}$ & $2.17 \mathrm{e}$ & $4.13 \mathrm{e}$ & $2.17 \mathrm{~cd}$ & $1.71 \mathrm{~cd}$ & $0.70 \mathrm{c}-\mathrm{e}$ & $0.41 \mathrm{c}-\mathrm{e}$ \\
\hline KW 516 x Scavina 6 & $0.46 \mathrm{ef}$ & $16.91 \mathrm{c}-\mathrm{e}$ & $2.60 \mathrm{de}$ & $4.83 \mathrm{~cd}$ & $1.27 \mathrm{e}$ & $1.85 b c$ & $0.71 \mathrm{c}-\mathrm{e}$ & $0.37 \mathrm{~d}-\mathrm{f}$ \\
\hline Sulawesi 3 x ICCRI 09 & $0.49 \mathrm{~d}$ & $18.41 \mathrm{a}$ & $2.73 \mathrm{~cd}$ & $4.47 \mathrm{de}$ & $2.40 \mathrm{~b}-\mathrm{d}$ & $1.65 \mathrm{de}$ & $0.72 b-e$ & $0.43 \mathrm{~b}-\mathrm{d}$ \\
\hline Sulawesi 3 x Scavina 6 & $0.46 \mathrm{ef}$ & $18.35 \mathrm{ab}$ & $2.77 \mathrm{~cd}$ & $4.27 \mathrm{de}$ & $2.00 \mathrm{~d}$ & $1.49 \mathrm{e}$ & $0.69 \mathrm{de}$ & $0.46 a-c$ \\
\hline TSH 858 x ICCRI 09 & 0.48 de & $16.21 \mathrm{e}$ & $2.83 \mathrm{~cd}$ & $5.90 \mathrm{ab}$ & $2.33 b-d$ & $2.22 \mathrm{a}$ & $0.71 \mathrm{c}-\mathrm{e}$ & $0.32 \mathrm{fg}$ \\
\hline TSH 858 x Scavina 6 & $0.53 \mathrm{ab}$ & $17.24 \mathrm{~cd}$ & $3.60 \mathrm{ab}$ & $6.43 \mathrm{a}$ & $2.34 b-d$ & $2.30 \mathrm{a}$ & $0.84 \mathrm{ab}$ & $0.36 \mathrm{~d}-\mathrm{f}$ \\
\hline Mean & 0.49 & 17.54 & 3.12 & 4.96 & 2.41 & 1.89 & 0.75 & 0.40 \\
\hline
\end{tabular}

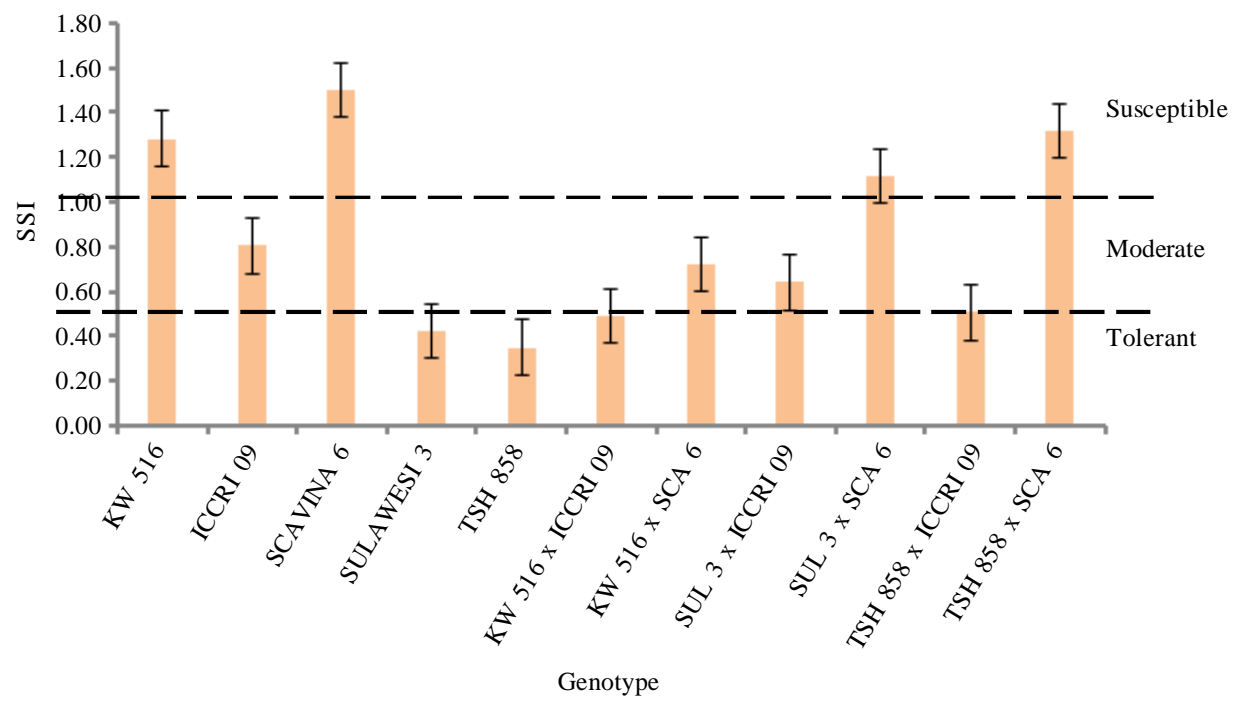

Figure 1. Drought susceptible index for 11 genotypes 


\section{CONCLUSIONS}

Based on general combining ability (GCA) and specific combining ability (SCA) value from analysis NCII mating-design, we found that TSH 858 was the best female parent, Scavina 6 was the best male parent, and Sulawesi 3 x ICCRI 09 and TSH 858 $\mathrm{x}$ Scavina 6 were the best crossing genotypes in this research. Characters which associated with drought stress were mostly controlled by additive genes. In this research we found that dominant genes influenced root fresh weight and root/shoot ratio. Based on SSI value we found that Sulawesi 3 and TSH 858 were tolerant parent, ICCRI 09 was moderate parent, and susceptible parent were KW 516 and Scavina 6. Some of the findings are in contrast with previous studies where TSH 858 was susceptible clone while Sca 6 was tolerant clone to drought. Crossing genotype classified as tolerant to drought stress was KW 516 x ICCRI 09, moderate genotype were KW 516 x Scavina 6, Sulawesi 3 x ICCRI 09, TSH 858 $x$ ICCRI 09, and susceptible genotypes were Sulawesi 3 x Scavina 6 and TSH 858 x Scavina 6.

\section{REFERENCES}

Acquaah, G. (2012). Principles of Plant Genetics and Breeding $2^{\text {nd }}$ ed. Wiley-Blackwell, Oxford.

Alban, M.K.A.; S.E. Apshara; K.B. Hebbar; T.G. Mathias \& A. Séverin (2016). Morpho-physiological criteria for assessment of two month old cocoa (Theobroma cacao L.) genotipes for drought tolerance. Indian Journal of Plant Physiology, 2, 23-30.

Ali, M.B. \& A.N. El-Sadek (2016). Evaluation of drought tolerance indices for wheat (Triticum aestivum L.) under irrigated and rainfed conditions. International Journal of The Faculty of Agriculture and Biology, 11, 77-89.
Beets, P.N.; S.H. Pearce; G.R. Oliver \& P.W. Clinton (2017). Root/shoot ratios for deriving below-ground biomass of Pinus Radiata stands. New Zealand Journal of Forestry Science, 37, 267-288.

BPS (2018). Statistik Kakao Indonesia 2017. Badan Pusat Statistik. Jakarta.

Constantin, M. (2017). Variability, Population Structure, Association Mapping and Genetic Parameters Estimation of Oil Palm (Elaeis guineensis Jacq.) Population from Cameroon. Bogor: IPB University, dissertation.

Derera, J.; P. Tongoona; B.S. Vivek \& M.D. Laing (2008). Gene action controlling grain yield and secondary traits in southern African maize hybrids under drought and non-drought environments. Euphytica, 162, 411-422.

Ditjenbun (2017). Statistik Perkebunana Indonesia 2015-2017, Kakao. Direktorat Jenderal Perkebunan. Jakarta.

Fasahat, P.; A. Rajabi; J.M. Rad \& J. Derera (2016). Principles and utilization of combining ability in plant breeding. Biometrics \& Biostatistics International Journal, 4, 1-24.

Hallauer, A.R. (2007). History contribution and future of quantitative genetics in plant breeding: lesson from maize. Crop Science, 47, 4-19.

Helmi, S. (2017). Respon Morfologi dan Fisiologi Tanaman Terung (Solanum melongena L.) terhadap Cekaman Salinitas. Bogor: IPB University, Thesis.

Hossein, M.R. \& K. Aziz (1998). Study of combining ability in maize line $\mathrm{x}$ tester hybridization. Pakistan Journal of Biological Science, 1, 196-198.

ICCO (2017). Production of cocoa beans. ICCO Quarterly Bulletin of Cocoa Statistic, $43,1$.

Iryono (2010). Uji Ketahanan Stress Kekeringan Beberapa Klon Kakao pada Berbagai Jenis Media pada Pembibitan. Thesis. Universitas Jember, Jember. 
Istipliler, D.; E. Ilker; F.A. Tonk; G. Civi \& M. Tosun (2015). Line $\mathrm{x}$ tester analysis and estimating combining abilities for yield and some yield components in bread wheat. Turkish Journal of Field Crops, 20, 72-77.

Kementan (2013). Peraturan Menteri Pertanian Nomor 131 Tahun 2013 tentang Pedoman Teknis Pembangunan Kebun Induk dan Kebun Entres Kakao. Kementan. Jakarta.

Khan, I.M. \& O.P. Dhurve (2016). Drought response indices for identification of drought tolerant genotypes in rainfed unpland rice (Oryza sativa L.). International Journal of Science, Environment and Technology, 5, 73-83.

Kurniawan, D. (2017). Pengaruh cekaman air terhadap pertumbuhan beberapa klon kakao (Theobroma cacao L.). Agroprimatech, 1, 18-25.

Lopes, U.V.; W.R. Monteiro; J.L. Pires; D. Clement; M.M. Yamada \& K.P. Gramacho (2011). Cacao breeding in Bahia, Brazil-strategies and result. $C B A B, 73-81$.

Luke, L.P.; M.B.M. Sathik; M. Thomas; L. Kuruvilla; K.V. Sumesh \& K. Annamalainathan (2015). Quantitative expression analysis of drought responsive genes in clones of Hevea with varying levels of drought tolerance. Physiology and Molecular Biology of Plants, 21, 179-186.

Medina, V. \& B. Laliberte (2017). A Review of Research on The Effects of Drought and Temperature Stress and Increased $\mathrm{CO}_{2}$ on Theobroma cacao L., and The Role of Genetic Diversity to Address Climate Change. CGIAR, Rome.

Monsterin, B.G. \& L.L. Verteuil (1956). Hybridization Work of Departement of Agriculture (Trinidad and Tobago) for The Control of Witches' Broom Disease of cacao. Instituto de Cacau da Bahia, Salvador.

Nduwumuremyi, A.; P. Tongoona \& S. Habimana (2013). Mating design: helpful tool for quantitative plant breeding analysis.
Journal of Plant Breeding and Genetic, 1, 117-129.

Santos, E.A.; A.A.F. Almaida; D. Ahnert; M.C.S. Branco; R.R. Valle \& V.C. Baligar (2016). Diallel analysis and growth parameters as selection tools for drought tolerance in young Theobroma cacao plants. Plos One, 11, 1-22.

Setyawan, B.; N. Puspitasari; A.W. Susilo \& I. Anita-Sari (2018). Rootstock characteristics of three combination of Theobroma cacao L. crosses on different water availability. Pelita Perkebunan, 34, 137-145.

Sprague, G.F. \& L.A. Tatum (1942). General versus specific combining ability in single crosses of corn. Juornal American Society Agronomy, 34, 923-932.

Syukur, M.; S. Sujiprihati \& R. Yunianti (2012). Teknik Pemuliaan Tanaman. Penebar Swadaya, Jakarta.

Tardieu, F. \& R. Tuberosa (2010). Dissection and modelling of abotic stress tolerance in plants, Current Opinion Plant Biology, 13, 206-212.

Towaha, J. \& E. Wardiana (2015). Evaluasi tingkat toleransi 35 genotipe kakao terhadap periode kering. Jurnal Tanaman Industri dan Penyegar, 2, 133-142.

Zakariyya, F.; B. Setyawan \& A.W. Susilo (2017). Stomatal, proline, and leaf water status characters of some cocoa clones (Theobroma cacao L.) on prolonged dry season. Pelita Perkebunan, 33, 109-117.

Zakariyya, F. (2017). Karakter morfologi perakaran beberapa semaian klon kakao asal biji. Seminar, Ekspo dan Diskusi (SEEDs) Perbenihan Nasional, hlm. 1-4. Jember, Indonesia.

$$
* * 0 * *
$$

